Special Issue (September)

\title{
PHARMACOGNOSTIC SCREENING STUDIES OF JUSTICIA GENDARUSSA BURM. LEAVES FOUND IN DEHRADUN DISTRICT OF UTTARAKHAND
}

\author{
NONDITA PRASAD ${ }^{1}$, BALBIR SINGH ${ }^{2 *}$, DIKSHA PURI ${ }^{3}$ \\ ${ }^{1}$ Department of Pharmaceutical Sciences, Lovely Professional University, Punjab, India. ${ }^{2}$ Department of Pharmaceutical Sciences, Guru \\ Nanak Dev University, Amritsar, India. ${ }^{3}$ Department of Ayurvedic Pharmaceutical Sciences, Lovely Professional University, Punjab, India. \\ Email: balbir_gndu@yahoo.com
}

Received: 14 July 2017, Revised and Accepted: 25 July 2017

ABSTRACT

Objective: Justicia gendarussa Burm. (family Acanthaceae) commonly known as nilinirgundi, is found in Southern India possesses multifarious biological activities due to large range of phytoconstituents. The present study is designed to evaluate the various pharmacognostic parameters of the leaves of J. gendarussa, found in Dehradun district of Uttarakhand for its authentication.

Methods: Fresh leaves were taken for the morphological and microscopical (histology and powder) evaluation. Physicochemical parameters (ash values, extractives values, florescence analysis, microbial contamination, and loss on drying) were also performed. Phytochemical screening and thinlayer chromatographic fingerprinting of extracts were also performed to check the presence of various phytoconstituents.

Results: The microscopy of the leaves evinced the presence of anisocytic stomata, cuboidal calcium oxalate crystals, cystoliths, multicellular covering trichomes, starch grains and oil globules. The quantitative estimation of total ash, acid insoluble, and water soluble ash values were $13.8 \%, 1.2 \%$, and $4.5 \% \mathrm{w} / \mathrm{w}$, respectively. The alcohol soluble and water soluble extractives were estimated as $11.45 \%$ and $15.67 \%$ w/w, respectively. Foreign organic matter and loss on drying values obtained were $0.23 \%$ and $11.2 \% \mathrm{w} / \mathrm{w}$. Phytochemical screening of petroleum ether, chloroform, methanol and aqueous extracts ascertained the presence of alkaloids, phenolic compounds, saponins, tannins, carbohydrates, flavonoids, glycosides, steroids and triterpenoids. The thin-layer chromatography (TLC) profiling of different extracts revealed the presence of potential compounds which can be further isolated with the help of high-performance liquid chromatography or high-performance TLC.

Conclusion: The results of this study provide suitable standards for the authentication of this plant. In the present study, there are certain variations observed from the evaluations done on the same species by other research groups. The probable reason suggested for such disparity is due to the environmental and geographical differences in the locations of the plant collected.

Keywords: Justicia gendarussa Burm., Leaves, Stomata, Macroscopy, Microscopy, Physicochemical evaluation, Phytochemical screening.

(C) 2017 The Authors. Published by Innovare Academic Sciences Pvt Ltd. This is an open accessarticle under the CC BY license (http://creativecommons. org/licenses/by/4. 0/) DOI: http://dx.doi.org/10.22159/ajpcr.2017.v10s4.21342

\section{INTRODUCTION}

Justicia gendarussa Burm. belonging to family Acanthaceae, commonly known as willow-leaved justicia or nillinirgundi, is a woody perennial shrub widely found in Asian countries such as Malaysia, Indonesia, Sri Lanka, and India. It is found widely distributed throughout the river beds of Southern India. The various parts of this plant are found to be traditionally used to cure various diseases such as liver disorders, inflammation, tumors, and skin diseases [1]. According to Indian and Chinese system of traditional medicine, the roots and leaves are enjoined to treat fever, respiratory disorders, hemiplegia, arthritis, muscle pain, rheumatism, headache, digestive tract problems, and in some cases of mental illness [2,3]. From the literature review, the plant is reported to have the potential antioxidant $[4,5]$, antimicrobial [5], anti-inflammatory [6], antinociceptive [6], antiarthritic [3], antifungal [7], antiangiogenic [8], analgesic [9], antianxiety [1], hepatoprotective [10], antibacterial [11], anticancer [12], anthelmintic [13], cytotoxic [14] and antiviral activities [15]. It is also used to treat the conditions such as amenorrhea and dysmenorrhea [16]. The whole plant is reported to contain flavonoids [17], steroids [15,18], alkaloids, phenolics, tannins and saponins [18]. Some important phytoconstituents are apigenin, vitexin, stigmasterol, campesterol, sitosterol [15], naringenin, kaempferol [14] and aromadedrin [19]. As this plant is having diverse therapeutic uses and lacking in standardization parameters, the present investigation was carried out to evaluate the leaves of
J. gendarussa for various pharmacognostic parameters which will be useful in its authentication and the preparation of monograph in the future.

\section{MATERIALS AND METHODS}

\section{Plant material}

Plant has been procured from the Indian Institute of Petroleum, Dehradun, India and it has been authenticated by National Bureau of Plant Genetic Resources, New Delhi, India with the Voucher Specimen No. NHCP/NBPGR/2012-41.

\section{Morphological and microscopic evaluation}

Fresh leaves were taken for the morphological and microscopical evaluation. The transverse sections were prepared and stained as per the standard procedures [20]. Thin transverse section of leaf was taken and observed under microscope to reveal the types of cells present in J. gendarussa plant. All the images for transverse section of leaf were first observed under 10x magnification of microscope, and then bright images were observed at $\times 40$ magnification of microscope so that perspicuous or lucid image were obtained. Dried powder of the leaves was taken for the powder microscopy [20].

Evaluation of physicochemical parameters

Various physicochemical parameters were performed such as percentage determination of total ash, acid insoluble ash, and water 
soluble ash, extractives values and loss on drying by using official methods and the WHO guidelines on quality control methods for medicinal plant materials [20].

\section{Florescence analysis}

A small quantity of dried powdered leaves was used to carry out the florescence analysis under day light, short (254 nm), and long (365 nm) ultraviolet radiations. The colors observed by application of various chemical reagents under the ultraviolet (UV) radiation exposure were recorded [20]

\section{Determination of microbial contamination}

Determination of bacterial and fungal growth was carried out using standard procedures [21]

\section{Preparation of extracts}

The dried plant material was coarsely powdered and $500 \mathrm{~g}$ of this powdered material was subjected to continuous Soxhlet extraction by using various solvents in their increasing order of polarity, namely, starting from petroleum ether $\left(60-80^{\circ} \mathrm{C}\right)$ (Loba-Chemie Ltd., Mumbai), chloroform (Thomas Baker, Mumbai), methanol (S.D Fine Chemicals Ltd., Mumbai), and finally digested with water for not $<48 \mathrm{hrs}$ [22].

\section{Phytochemical analysis}

Preliminary phytochemical screening was done to check the presence of alkaloids, saponins, carbohydrates, glycosides, flavonoids, steroids, triterpenoids, phenolic compounds, and tanins using the standard procedures [23].

\section{Thin-layer chromatography (TLC) fingerprinting of extracts}

TLC is a method for analyzing mixtures and determining the number of components present in it. It is also used for the identification and check the purity of a compound. The identification of separated compounds can be achieved on the basis of their retention factor (Rf) values. Sample preparation was done by taking $1 \mathrm{~g}$ of each petroleum ether, chloroform, methanol, and aqueous extracts of J. gendarussa and dissolved in $10 \mathrm{ml}$ of their respective solvents. A spot was loaded on TLC plate by using a fine capillary. The spots were observed under visible light, long UV (365 nm), and short UV (254 nm) and in iodine chamber [24]

\section{RESULTS}

\section{Macroscopy}

Macroscopy of leaves of J. gendarussa was carried out and organoleptic characteristics were observed as green and the leaf blade was lanceolate to ovate to elliptic to subcircular. Midrib and veins were of prominent violet on the lower surface. The size of leaf was measured about 7.5-12.5 cm long and often wider than $1.5 \mathrm{~cm}$. The leaves in powdered form exhibits pale green color. It was odorless and taste was slightly bitter.

\section{Microscopy}

\section{Transverse section of leaf}

The thin transverse section of the leaf midrib revealed the presence of a single-layered epidermis covered externally with cuticle and presence of multicellular covering trichomes (Fig. 1a). Upper and lower epidermal layers were composed of rectangular cells. Collenchyma (Fig. 1b and c) was present below the upper epidermis which was well developed and cells were round to polygonal in shape. Compactly arranged parenchymatous cells (Fig. 1b and c) were also observed. It was clear from Fig. 1b, that spongy parenchyma cells were round. Endodermis layer surrounded the whole vascular bundle. Vascular bundles (Fig. 1b) were well developed with xylem vessels and phloem fibers which were radially arranged. A layer of cystolith (Fig. 1c) was present just above the lower epidermis. The leaf was peeled off and examined under the microscope after treating it with chloral hydrate and mounting was done with glycerin which revealed the presence of anisocytic (cruciferous or unequal celled) stomata (Fig. 2).

\section{Powder microsopy}

Powder of leaves after treatment with suitable reagents were observed under $\times 10$ magnification revealed the presence of cuboidal calcium oxalate crystals (Fig. 3a), cystolith (Fig. 3b), multicellular covering trichomes (Fig. 3c), clusters of starch grains (Fig. 3d), and oil globules (Fig. 3e).

\section{Physicochemical evaluation}

The results of physicochemical parameters are shown in Table 1.

\section{Florescence analysis}

Florescence analysis under day light, short (254 nm), and long (365 nm) ultraviolet radiations is shown in Table 2 .
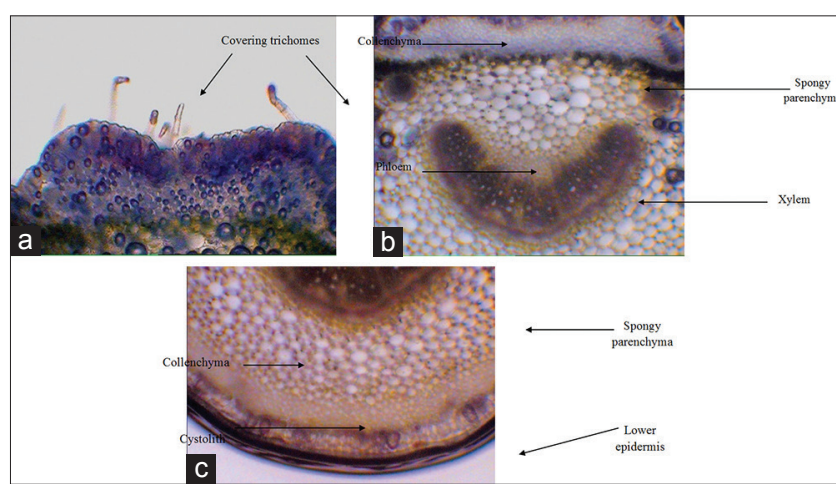

Fig. 1: Transverse section of the leaf showing, (a) covering trichomes (b) collenchyma, phloem fibers, xylem vessels and spongy parenchyma (c) spongy parenchyma, collenchyma, cystolith and lower epidermis

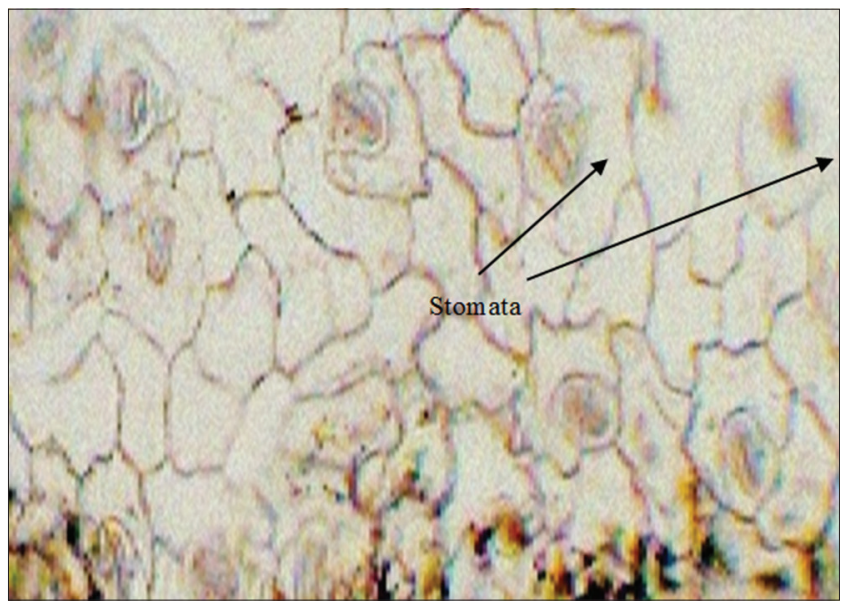

Fig. 2: Surface of leaf showing anisocytic stomata

Table 1: Physicochemical evaluation of J. gendarussa

\begin{tabular}{lll}
\hline S. No. & Physical parameters & $\begin{array}{l}\text { \% Value } \\
\text { obtained } \mathbf{( w / w )}\end{array}$ \\
\hline 1. & Foreign organic matter & 0.23 \\
2. & Loss on drying & 11.2 \\
3. & Total ash & 13.8 \\
4. & Acid insoluble ash & 1.2 \\
5. & Water insoluble ash & 4.5 \\
6. & Alcohol soluble extractive value & 11.45 \\
7. & Water soluble extractive value & 15.67 \\
\hline J. gendarussa: & Justicia gendarussa
\end{tabular}




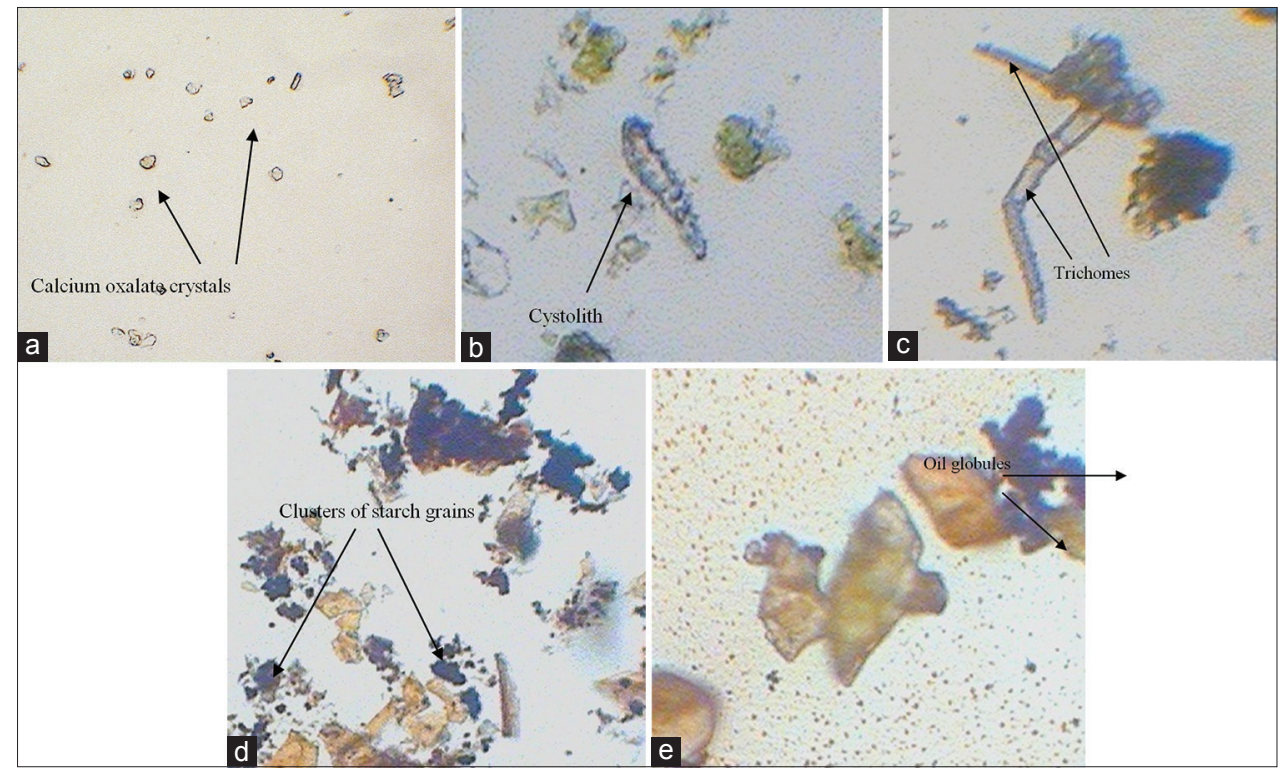

Fig. 3: Photomicrographs of Justicia gendarussa leaf powder showing (a) cuboidal calcium oxalate crystals, (b) cystolith, (c) covering trichomes, (d) clusters of starch grains and (e) oil globules

Table 2: Florescence analysis of $J$. gendarussa

\begin{tabular}{llll}
\hline Solvent used & Color under visible light & Color under long UV (365 nm) & Color under short UV (254 nm) \\
\hline Petroleum ether & Light green & Purple brown fluorescence & Yellow fluorescence \\
Concentrated nitric acid & Light green & Nil & Nil \\
Concentrated ammonia & Light green & Nil & Nil \\
Concentrated hydrochloric acid & Dark green & Nil & Nil \\
Concentrated sulphuric acid & Dark green & Purple fluorescence & Nil \\
Ethanol & Light green & Nil & Purple brown fluorescence \\
lodine & Black & & \\
\hline
\end{tabular}

J. gendarussa: Justicia gendarussa, UV: Ultraviolet

Table 3: Microbial contamination of $J$. gendarussa

\begin{tabular}{lll}
\hline Drug name & Bacterial growth & Fungal growth \\
\hline J. gendarussa & Nil & Nil \\
\hline J. gendarussa: Justicia gendarussa &
\end{tabular}

\section{Microbial contamination}

The powdered plant material was subjected to microbial contamination test to check the fungal and bacterial growths present in it (Table 3).

\section{Preliminary phytochemical screening}

Preliminary phytochemical screening mainly revealed the presence of alkaloids, phenolic compounds, tannins, saponins, carbohydrates, glycosides, flavonoids, steroids, and triterpenoids in various extracts (Table 4).

\section{TLC profiling of different extracts}

The chromatograms developed for petroleum ether extract (Fig. 4a), chloroform extract (Fig. 4b) methanol extract (Fig. 4c), and aqueous extract (Fig. 4d) are shown below.

\section{DISCUSSION}

The standardization of a crude drug is a very important parameter for checking its quality and purity. As the $80 \%$ of the world population is depending upon the natural products as their primary healthcare, the need of standardization is becoming more vital now. The true identity of a crude drug can be established by its standardization. The present study was undertaken to lay down the standards which could be useful in substantiate and authenticate this medicinally potent plant in future.
Macroscopic and microscopic identification of the crude drug is the simplest and cheapest method to identify a crude drug. The transverse section of leaf and the powder microscopy revealed the presence of anisocytic stomata, cuboidal calcium oxalate crystals, cystoliths, multicellular covering trichomes, starch grains, and oil globules. The values obtained from parameters such as ash value, extractive value, florescence analysis and loss on drying will be helpful in authentication of the crude drug. Preliminary phytochemical screening was done for four different extracts and ascertained the presence of steroids and triterpenoids in petroleum ether extract; chloroform extract was containing alkaloids, phenolic compounds, tannins, and carbohydrates; methanol extract showed the presence of alkaloids, phenolic compounds, tannins, saponins, carbohydrates, glycosides, and flavonoids; aqueous extract gave positive tests for alkaloids, phenolic compounds, tannins, saponins, and carbohydrates. The TLC profiling of different extracts in suitable solvent systems revealed the presence of potential compounds which can be further isolated in future with the help of high-performance liquid chromatography or high-performance TLC.

In the conclusion, the parameters which have been reported in the present study could be proven useful to lay down standards which can be helpful in authentication and preparation of a monograph of this plant. There are certain variations observed in the present study from the previous study carried out by the Sonal et al. in 2011 on the same species collected from the Gujarat location [25]. But there are certain variations observed and moreover the glycoside content was found in both chloroform and methanol extracts of the plant collected from Dehradun region. The probable reason for such disparity is due to the environmental and geographical differences in the locations of the plant collected. 
Table 4: Preliminary phytochemical screening for J. gendarussa leaf extracts

\begin{tabular}{|c|c|c|c|c|c|}
\hline S.No. & Phytochemical constituents & Petroleum ether extract & Chloroform extract & Methanol extract & Aqueous extract \\
\hline \multirow[t]{5}{*}{1.} & Alkaloids & & & & \\
\hline & Hager's test & - & - & + & + \\
\hline & Mayer's test & - & - & + & + \\
\hline & Dragendorff's test & - & - & + & + \\
\hline & Wagner's test & - & + & - & + \\
\hline \multirow[t]{4}{*}{2.} & Phenolic compounds and Tanins & & & & \\
\hline & Bromine water test & - & - & - & + \\
\hline & Lead acetate test & - & + & + & + \\
\hline & Ferric chloride test & - & - & + & + \\
\hline \multirow[t]{2}{*}{3.} & Saponin & & & & \\
\hline & Frothing test & - & - & + & + \\
\hline \multirow[t]{3}{*}{4.} & Carbohydrates & & & & \\
\hline & Fehling's test & - & - & + & + \\
\hline & Molisch test & - & + & + & + \\
\hline 5. & Glycosides & & & & \\
\hline \multirow[t]{3}{*}{7.} & Flavonoids & & & & \\
\hline & Shinoda test & - & - & + & - \\
\hline & Alkaline reagent test & - & - & + & - \\
\hline \multirow[t]{3}{*}{8.} & Steroids and triterpenoids & & & & \\
\hline & Libermann Burchard test & + & - & - & - \\
\hline & Liebermann's test & + & - & - & - \\
\hline
\end{tabular}

$+:$ Indicates the presence and -: Indicates the absence of the respective chemical class in the extracts. J. gendarussa: Justicia gendarussa

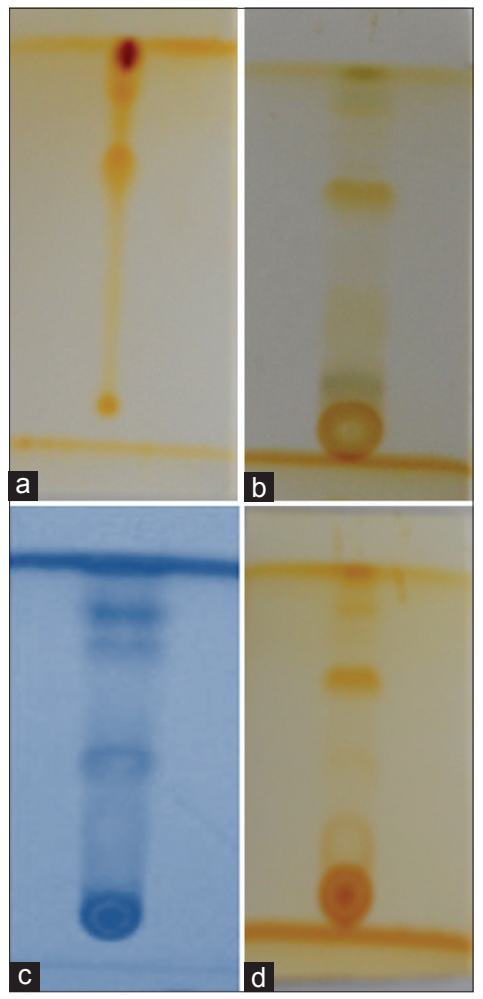

Fig. 4: Thin layer chromatography profiles of Justicia gendarussa (a) petroleum ether extract, (b) chloroform extract and (c) methanol extract and (d) aqueous extract

\section{REFERENCES}

1. Subramanian N, Jothimanivannan C, Kumar RS, Kameshwaran S. Evaluation of anti-anxiety activity of Justicia gendarussa Burm. Pharmacologia 2013;4(5):404-7.

2. Chandrasekar R, Chandrasekar S. Natural herbal treatment for rheumatoid arthritis - A review. Int J Pharm Sci Res 2017;8(2):368-84.

3. Paval J, Kaitheri SK, Potu BK, Govindan S, Kumar RS, Narayanan SN, et al. Anti-arthritic potential of the plant Justicia gendarussa Burm F. Clinics (Sao Paulo) 2009;64(4):357-62.

4. Mrunthunjaya K, Hukkeri VI. Antioxidant and free radical scavenging potential of $J$. gendarussa Burm, leaves in vitro. Nat Prod Sci 2007;13(3):199-206.

5. Uddin R, Sinha S, Hossain A, Kaisar A, Hossain K, Rashid MA. Chemical and biological investigations of Justicia gendarussa (Burm. f). Dhaka Univ J Pharm Sci 2011;10(1):53-7.

6. Shikha P, Latha PG, Suja SR, Anuja GI, Shyamal S, Shine VJ, et al. Anti-inflammatory and anti-nociceptive activity of Justicia gendarussa Burm f. Leaves. Indian J Nat Prod Resour 2010;1(4):456-61.

7. Sharma KK, Saikia R, Kotoky J, Kalita JC, Devi R. Antifungalactivity of Solanum melongena L, Lawsonia inermis L. And Justicia gendarussa B. Against dermatophytes. Int J PharmTech Res 2011;3(3):1636-40.

8. Periyanayagam K, Umamaheswari B, Suseela L, Padmini M, Ismail M. Evaluation of antiangiogenic effect of the leaves of Justicia gendarussa (Burm. f) (Acanthaceae) by chrioallontoic membrane method. Am J Infect Dis 2009;5(3):180-2.

9. Jothimanivannan C, Kumar RS, Subramanian N. Anti-inflammatory and analgesic activities of ethanol extract of aerial parts of Justicia gendarussa Burm. Int J Pharmacol 2010;6(3):278-83.

10. Krishna KL, Mruthunjaya K, Jagruti AP. Antioxidant and hepatoprotective potential of stem methanolic extractof Justicia gendarussa Burm. Int J Pharmacol 2010;6(2):72-80.

11. Siva SA, Vijayalakshmi M. In vitro evaluation of antibacterial activity of chloroform extract from Justicia gendarussa. Int J Ethnomed Pharmacol Res 2013;1(1):88-91.

12. Zahidah A, Azman AS, Siti PM. Cytotoxicity activities in local Justicia gendarussa crude extracts against human cancer cell lines. Jurnalteknologi 2013;64(2):45-52.

13. Saha MR, Debnath PC, Rahman MA, Islam MA. Evaluation of in vitro anthelmintic activities of leaf and stem extracts of Justicia gendarussa. Bangladesh J Pharmacol 2012;7:50-3.

14. Zahidah A, Azman AS, Siti PM, Jamil S. Cytotoxic activities against breast cancer cells of local Justicia gendarussa crude extracts. Evid Based Complement Alternat Med 2014;2014:1-12.

15. Correa GM, Alcantara AF. Chemical constituents and biological activities of species of Justicia - A review. Rev Bras Farmacogn Braz J Pharmacogn 2012;22(1):220-38.

16. Agastian P, Williams L, Ignacimuthu S. In vitro propagation of Justicia gendarussa Burm f. - A medicinal plant. Indian J Biotechnol 2006;5:246-8

17. Ayob Z, Saari NH, Samad AA. In Vitro Propagation and Flavonoid Contents in Local Justicia gendarussa Burm. F. UMT $11^{\text {th }}$ International 
Annual Symposium on Sustainability Science and Management; 2012. p403-409.

18. Bhagya $\mathrm{N}$, Chandrashekar KR. In vitro production of bioactive compounds from stem and leaf explants of Justicia gendarussa Burm. f. Asian J Pharm Clin Res 2013;6(1):100-5.

19. Bader GN, Mir PA, Bhat ZA. Present status of anti-inflammatory and antirheumatic phytoconstituents: A review. World J Pharm Pharm Sci 2014;3(11):272-310.

20. WHO. Quality Control Methods for Medicinal Plant Materials. Geneva, England: World Health Organization; 1998.

21. Kandasamy CS, Nath S, Arulraj P, Gopal V, Muthusamy P, Venkatanarayanan R. Anti-microbial activity of the crude drugs and the polyherbal formulation (RVSPHF567) by standardized cup and plate method. Int J Pharm Sci Res 2011;2(10):189-95.

22. Aiswarya G, Gupta R, Kambhoja S. Isolation of 28-pentyl-3-galloylbetulinate and11-hydroxy friedelane from the plant Argyreia speciosa. Res J Pharm Biol Chem Sci 2010;1(3):207-21.

23. Khandelwal KR. Preliminary Phytochemical Screening in Practical Pharmacognosy. $18^{\text {th }}$ ed. Pune: Niralli Parkashan; 2004. p. 149-56.

24. Kagan IA, Flythe MD. Thin-layer chromatographic (TLC) separations and bioassays of plant extracts to identify antimicrobial compounds. J Vis Exp 2014;85.

25. Sonal P, Nayana K, Bakula S, Mamta S. Botanical identification and physicochemical investigation of leaf of Nili-nirgundi (Justicia gendarussa). Int J Pharm Sci Rev Res 2011;10(1):116-21. 